Communication

\title{
Dust Accumulation on the Surface of Photovoltaic Panels: Introducing the Photovoltaic Soiling Index (PVSI)
}

\section{Karim Menoufi}

Renewable Energy Sciences and Engineering Department, Faculty of Postgraduate Studies for Advanced Sciences, Beni-Suef University, P.O. Box 62511, Beni-Suef, Egypt; karim.menoufi@psas.bsu.edu.eg or karim_menoufi@hotmail.com; Tel.: +20-1222280481

Academic Editor: Tomonobu Senjyu

Received: 2 May 2017; Accepted: 2 June 2017; Published: 6 June 2017

\begin{abstract}
This article presents an empirical review of research concerning the impact of dust accumulation on the performance of photovoltaic (PV) panels. After examining the articles published in international scientific journals, many differences between the studies were found within the context of the PV technologies used, the contribution to this type of study from different countries, and the variety in the representation of the results where each study has its unique parameters, testing equipment, and relevant standards. Due to those variations and differences, it has been found that it is very difficult and impractical to compare between results of the corresponding studies. Hence, in addition to the valuable reviews found in literature, this article demonstrates another new perspective that highlights the gaps in the studies related to the impact of dust accumulation on PV panels. The conclusions of this study are considered to be the seed for establishing a new initiative-The Photovoltaic Soiling Index (PVSI)—which would be an indicator for the performance of PV panels under exposure to dust at the Standard Test Conditions (STC), as well as at other operating conditions in different locations around the globe.
\end{abstract}

Keywords: soiling; photovoltaic (PV); dust; pollutant; solar energy; Photovoltaic Soiling Index (PVSI); Standard Test Conditions (STC)

\section{Introduction}

The exploitation of renewable energy resources for power generation has become a topic of global concern. The member states of the European Union, as well as a growing number of other countries, have placed high priority on renewable energy sources and created respective targets [1], for example, the European Union envisages a renewable energy share of $20 \%$ in final energy consumption by 2020 . This reflects the importance and significance of renewable energy technologies that are penetrating the markets worldwide, and seeking positions in a growing world that is moving towards the diversity of the power resources and energy systems.

There has been tremendous growth in the utilization of renewable energy and specifically solar energy technologies [2], especially after the oil crisis during the late 1970s. Such a crisis has compelled scientists and policymakers around the world to find different ways of harnessing solar energy more effectively and efficiently. For terrestrial applications, solar energy can be exploited in two different ways; through solar thermal systems using solar collectors, heaters, dryers, etc. as well as through solar electrical systems using PV technologies.

The current status of solar energy is also of note, as it is the leading sector for investment, accounting for $55 \%$ of total new investment in non-hydro renewable energy. The major share of those 
investments within the solar sector is for PV technologies, resulting in a cumulative global PV installed capacity of $177 \mathrm{GW}$ [3].

Much research has been conducted on the development of various types of PV devices. PV devices have been classified into three generations according to the materials and technologies used in the fabrication, starting with crystalline silicon PV cells, and progressing towards other materials and technologies such as organic and polymer materials, dye-sensitized PV cells, quantum dots, hot carriers, and carbon nanotubes [4-8]. Other studies regarding PV technologies exist in the literature as well. Such studies consider the engineering applications of PV systems, such as solar water heaters, solar air heater/dryers, solar desalination, solar home lighting, concentrated PV, and Building Integrated Photovoltaic (BIPV). Moreover, a wide range of related studies can be found concerning the feasibility and Life Cycle Assessment of PV systems [9-15]. The main essence of all these research projects is to examine the factors that affect the performance of PV devices and consequently look for potential improvements. In that same context, many research works in the literature compare the performance of PV devices within different operating conditions [16-20]. One of the most essential and critical factors in that sense is the impact of dust accumulation on the performance of PV panels, on which numerous studies have been published. In the present article, an empirical analysis based on a thorough review has been conducted. The surveyed articles have been carefully analyzed, and the objective of this paper is to present a review of the impact of dust accumulation on the performance of PV panels from an empirical viewpoint. Moreover, the conclusions and recommendations of this article can be considered as the starting point for encouraging the standardization of research that concerns the impact of dust accumulation on the performance of PV panels, through the development of a "dust coefficient" for PV devices (The Photovoltaic Soiling Index-PVSI). The creation of the PVSI would encourage deriving a common standard for future studies, so that the results of different studies in different locations could be compared to each other. The PVSI would also serve as an indicator for the performance of PV panels under the effect of accumulated dust for specific defined periods of time and under different operating conditions.

\section{Materials and Methods}

Based on the widely known and generic meaning of empirical research [21-23], we find that an empirical review is a way of presenting information and knowledge by means of direct and indirect observation of the reviewed subject. Empirical evidence in such a case (the record of one's direct observations or experiences) can be analyzed quantitatively or qualitatively, through quantifying the evidence or making sense of it in qualitative form. Hence, in this article, we present the knowledge based on analyzing and observing published articles on the subject of dust accumulation on PV panels. Additionally, we present arguments and observations in the form of graphs and statistics, from which we build our conclusions in a qualitative form, exposing the findings of the study and suggesting new concepts and recommendations.

After conducting a comprehensive literature review that focused on the work published in international journals starting from the year 1990 and until the end of the year 2016, 73 studies were found to be directly related to analyzing the impact of dust accumulation on the performance of PV panels. As a result, those studies have been classified in this article into two categories: review articles [24-34], and original research articles [35-96] which contain practical case studies.

Regarding the review articles, it has been found that each study has approached the corresponding research subject from a distinct viewpoint. Mani and Pillai, 2010 [24] achieved an appraisal on the status of research in that specific area. Mekhilef et al., 2012 [25] reviewed the technical parameters of PV modules that are mostly affected by the accumulation of dust. Darwish et al., 2013 [26] reviewed the effect of some environmental variables on the performance of PV modules. Sarver et al., 2013 [27] presented a comprehensive overview of soiling problems, primarily those associated with dust and combined dust-moisture conditions. Ghazi et al., 2014 [28] assessed the patterns of dust distribution and accumulation in distinct parts of the world. Kazem et al., 2014 [29] achieved a review of the 
geographical and meteorological characteristics in Iraq to clarify dust causes, types, specifications, and the corresponding impact on PV panels. Sayyah et al., 2014 [30] conducted a review that comprised some of the major studies reported on energy-yield losses in different PV plants in several regions of the world. Darwish et al., 2015 [31] presented a review concerning the effects of different types of pollutants on the performance of PV devices, taking into consideration indoor and outdoor experimentations. Costa et al., 2016 [32] presented a literature review update concerning the dust and soiling issues related to solar energy systems during the time period from 2012 to 2015. Maghami et al., 2016 [33] reviewed the factors that affect the optimum yield generation of PV panels, where the authors divided the shading into two types caused by dust and soiling: soft shading and hard shading. Zaihidee et al., 2016 [34] reviewed and summarized the impacts of dust on the efficiency of PV panels and the factors that affect the dust deposition on their surfaces.

For original research articles/case studies, [35-96] they can be divided into two groups:

- Electrical performance studies: Most of the studies surveyed covered electrical performance aspects and parameters, represented in measuring several parameters of dusty/polluted PV modules in comparison to clean PV modules, such as the short circuit current, the maximum current, the open circuit voltage, the maximum voltage, the output power, the energy output, and the other weather parameters (solar radiation, air humidity, wind speed, air temperature, and PV panel surface temperature).

- Optical performance studies: Only a few studies were found regarding this aspect, where the optical transmittance of dusty/polluted PV panels were measured and presented according to the dust density on their surfaces [74]. Moreover, some of these studies demonstrated the transmittance results in correlation to other parameters, such as different tilt angles of PV modules [28], the number of days of exposure of PV panels to the outdoor dust/polluted environment [69], and the dust deposition density [41]. Numerical simulation and other theoretical analysis tools were rarely utilized [87].

\section{Results and Discussion}

Based on the previous analyses, some results can be derived as follows:

- An increased interest has been spotted during the last six years regarding the field of studying the impact of dust accumulation on the performance of PV panels, specifically starting from the year 2011 (Figure 1). The largest number of studies were published during the year 2016. This reflects the growth in utilizing PV technology as a source of renewable energy worldwide, which motivates conducting further studies on the factors that affect its efficiency, such as the accumulation of dust, temperature variations, and other factors. Following that, a related trend of studies can be found in the literature concerning dust mitigation techniques as well [97,98]. The explanations presented in Figure 1 are compatible with the fact that the PV industry has been strengthened over the years 2015 and 2016 due to the continued emergence of new markets and the associated strong global demand, in addition to the reduction in the prices of PV technologies and corresponding system components [99]. 


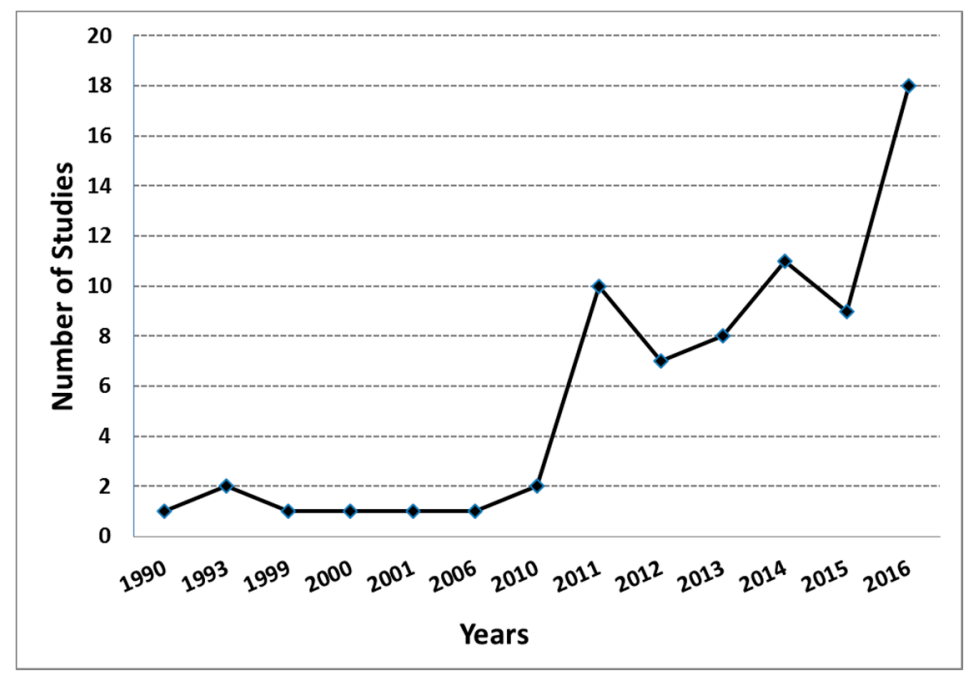

Figure 1. Demonstration of the increasing interest in the field of studying the impact of dust accumulation on the performance of PV.

- Figure 2 shows the contribution of different continents to studies related to the impact of dust accumulation on PV modules. It is shown that almost half of the studies surveyed come from Asia, where the majority of studies are from the Kingdom of Saudi Arabia (KSA), Malaysia, and India. The KSA has been found to be the country that generates the largest number of studies not only in Asia but among the rest of the world as well. It is noted that although the Middle East, Africa, and Asia are well-known to contain more arid, windy, and dusty environments, most of the studies emerged from Asia only.

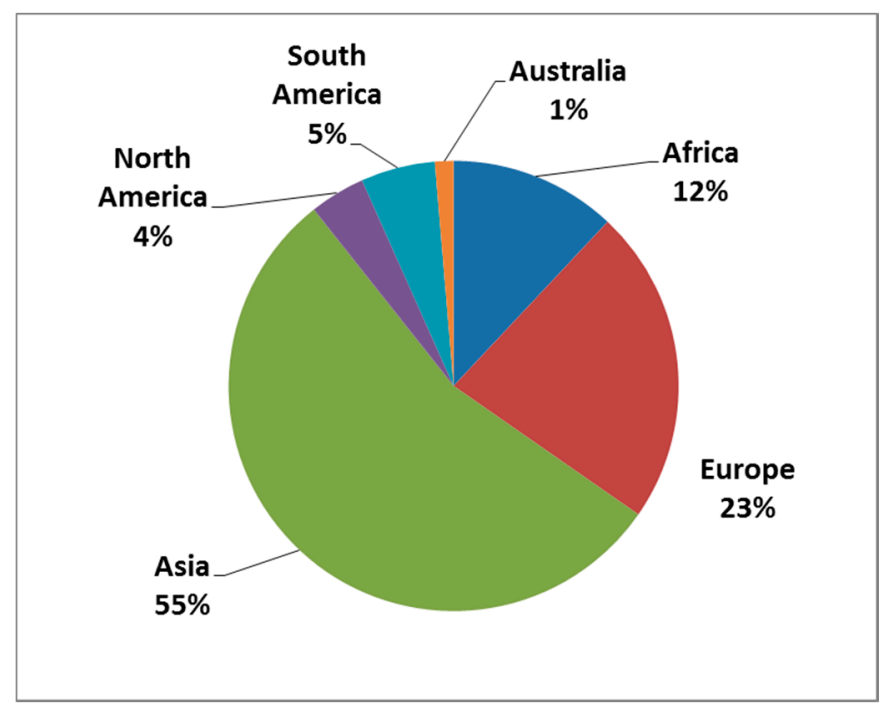

Figure 2. Contribution percentage of different continents to the studies of the impact of dust on PV panels.

The dominance of Asia in this trend of studies can be attributed to two reasons. First, Asia had the greatest share of the world markets regarding added PV installations for the third consecutive year in 2015, accounting for about $60 \%$ of global additions [99]. Second, Asia is a major dust source in the world, that is, mineral dusts in the atmosphere and their interactions with clouds and precipitation have great impacts on the regional climate in Asia, where there are large arid and semiarid regions [100,101]. 
These could be considered significant motives for producing more research works related to dust accumulation on the surface of PV panels. On the other hand, it has been found that the share of Africa from the surveyed studies is only $12 \%$, although Africa is one of the worst dust accumulation zones in the world, in addition to the fact that the there are many initiatives that support renewable energy cooperation between Europe and Africa [102]. Europe comes next after Asia in conducting studies on the impact of dust accumulation on PV panels, as $23 \%$ of the published studies came from Europe. This percentage is considered significant, as Europe does not suffer significantly from the dust accumulation problem compared to other parts of the world such as Asia, the Middle East, and Africa. This also reflects the significant interest in research on the factors that affect the performance of PV devices in the European continent. Regarding the types of PV technologies considered in the corresponding research works, multicrystalline silicon PV technology was found to be the most utilized type, followed by the monocrystalline PV modules (Figure 3). Moreover, it was found that around 19\% of the surveyed studies did not clearly mention the type of the PV module technology tested. It was also noticed that thin film technology is considered in a very few number of studies compared to multicrystalline and monocrystalline technologies. This is because multicrystalline PV panels are the most utilized in different applications (residential, commercial, etc.) and in the research projects, as well due to their wide availability and reduced prices, despite the fact that their efficiency ranges are normally lower than those of monocrystalline PV panels. Nevertheless, monoscrystalline PV panels have also started to gain a larger share of production, especially during the year 2015 [99].

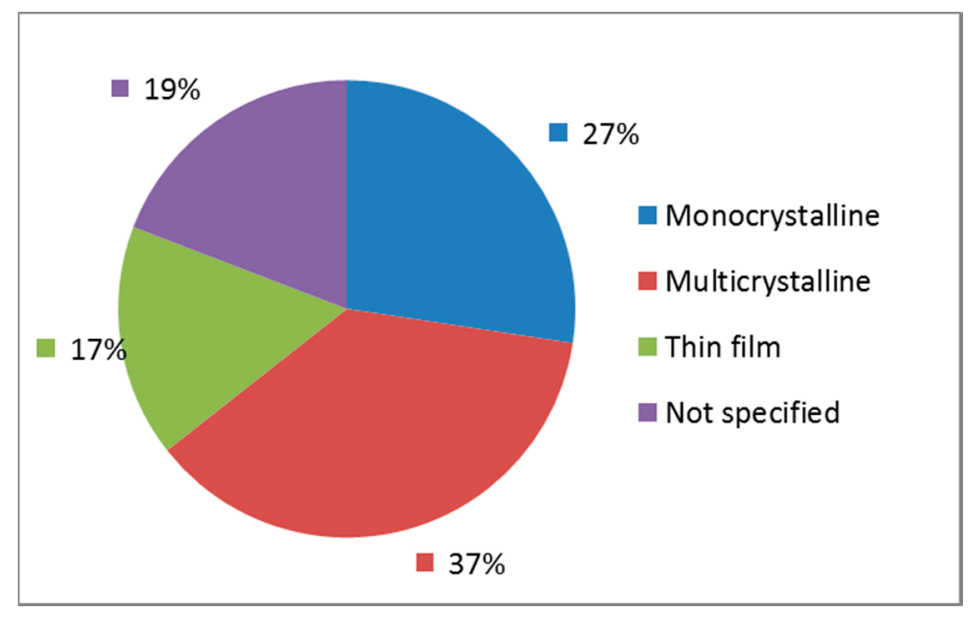

Figure 3. The types of PV device technologies found in the surveyed research articles.

During the conducted experiments, most of the studies considered the natural dust accumulation over the surface of PV panels, while the dust/pollutant was deposited artificially in some other studies. Within the studies on natural dust accumulation, it was found that the exposure time periods differed from one study to another. Regarding the studies that deposited the dust artificially, it was found that different types of pollutants are considered other than natural dust, such as ash and lime (Figure 4). However, it is worth mentioning that the accumulation of dust (naturally or artificially) was not found to be related to the indoor and outdoor testing of dusty/polluted PV panels. That is, some authors in their corresponding research exposed PV panels in order to allow for the accumulation of dust naturally on the surface; however, electrical performance evaluations were conducted indoors, through exposing the panels to artificial sources of light rather than natural sunlight, and then the necessary measurements were recorded. Hence, in this way, the dust was accumulated "outdoors", but the electrical testing took place "indoors". Additionally, no studies were found to have considered the electrical performance evaluation of PV panels under the Standard Test Conditions (STC). 


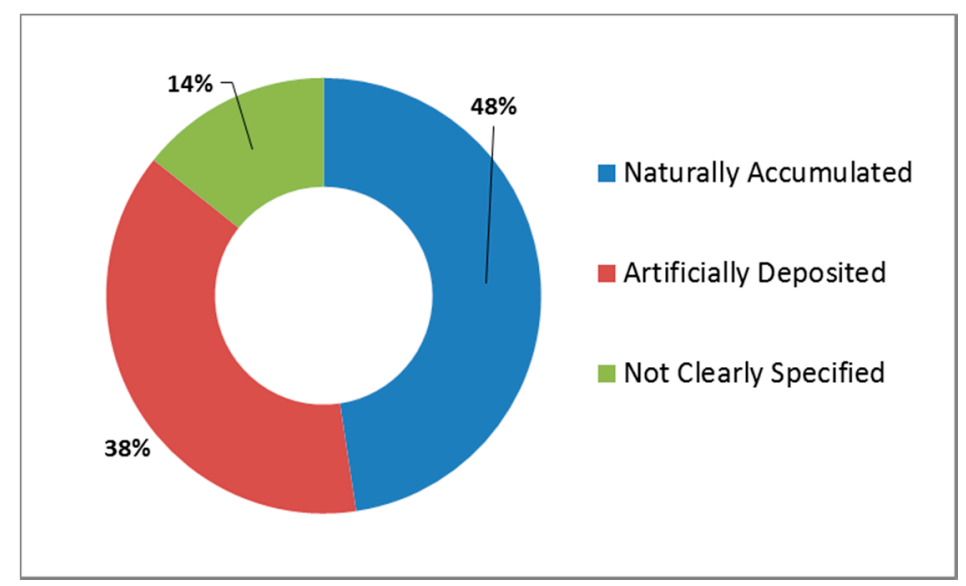

Figure 4. The dust accumulation method, varied between collecting the dust naturally and depositing it artificially.

Referring to the electrical experimentation and testing parameters, it was noted that very few studies had taken into consideration an approved standard for testing, such as the IEC-6089 (Photovoltaic devices-Procedures for temperature and irradiance corrections to measured I-V characteristics) [45]. In addition, not all of the studies were found to have measured the same exact parameters, instead, several variations were found to be demonstrated in the results. For example, some studies demonstrated the typical graphic results of the I-V characteristics of a PV panel, while other studies presented the electrical performance parameters in terms of a P-V curve $[73,80]$. Moreover, some studies were found to be interested in examining the composition of the accumulated dust on the corresponding PV panels, as well as the distribution and particle size of the dust/pollutants, and their correlation to the solar irradiance, efficiency, and fill factor, among many other parameters $[44,58,76]$.

The surveyed studies exhibited the utilization of different testing equipment without referring to any calibration procedures that took place before the experiments. A large variety of testing equipment was found in that sense, ranging from simple resistor circuits [50], I-V source meter devices [82], to even precise large-scale PV analyzers [58].

\section{Conclusions and Recommendations}

This article reviews published research regarding the impact of dust accumulation on the performance of PV panels from an empirical viewpoint. The article examined the similarities and differences between the studies regarding many aspects: The countries contributing to that field of study, the measured parameters, the standards considered, the pollutant types (dust, ash, lime, etc.), the pollutant deposition (natural or artificial), and the type of PV technologies utilized. It was found that Asia is the continent with the most published studies in this field, followed by Europe. Although Africa has been identified in previous research as one of the worst dust accumulation zones in the world, a significant lack of corresponding studies was noticed. Therefore, it is recommended that more studies should be directed towards the impact of dust accumulation on the performance PV modules in Africa, especially in view of the fact that the renewable energy sector is expected to grow significantly out there [101,103]. Regarding the tested PV technologies, multicrystalline technology was found to be the most utilized method in the corresponding experiments.

From another viewpoint, many differences were found between the studies, which made the comparison between their results inapplicable. First of all, the surveyed studies came from different locations around the world, where each location has its own unique geographical and meteorological characteristics. Moreover, some studies considered the electrical performance of PV panels, where others considered the optical transmittance parameters. Even within the electrical performance testing, the results were found to be widely varied, using different scales, values, equipment, measured 
parameters, correlations, and testing environments (indoors and outdoors). In addition to this, the corresponding tested PV modules were found to be different in the power ratings as well as the technology type. Regarding the dust accumulation process, it was found that the periods of exposure of the PV panels to dust (in the case of natural dust accumulation) were different and sometimes not specified. Some studies considered the deposition of the dust artificially on the surface of PV panels without exposing the panels to outdoor environments. No studies were found to be interested in testing the electrical performance of dust/polluted PV modules under Standard Test Conditions (STC).

Hence, based on the aforementioned differences, a common testing protocol for conducting the experiments to examine the impact of dust accumulation on PV panels could to be derived, so that researchers could employ a standard protocol whenever they need to produce articles that are comparable to those of their peers. Such a testing protocol would assist in the development of the Photovoltaic Soiling Index (PVSI), which is a suggested "dust coefficient" for PV devices used to correlate between the accumulation of dust on the surface of PV panels and their electrical performance in specific locations and within specific time periods. The PVSI concept could also be integrated as follows:

- The PVSI could be developed as an essential parameter in the datasheets of PV modules, which is-by analogy-similar to the temperature coefficient parameters that demonstrate the rate of change of the output power from a PV panel due to the change in the PV cells temperature. Within the PVSI context, the percentage reduction in the output power of the PV panel due to the accumulation of dust particles of specific size, distribution, and density could be evaluated in different locations, at different operating conditions, and under Standard Test Conditions (STC) as well.

- The PVSI could also be implemented through creating interactive online maps, based on the development of a database for calculating the average dust density and dust deposition rate during the four seasons of the year over different countries and continents. Such a database would be implemented taking into consideration the necessary spatial resolution as well as the suitable interpolation in order to estimate the dust density and deposition rates in correlation with other parameters, such as solar irradiance, ambient temperature, and PV module temperature. Such data could be obtained through standardized steps of continuous electrical field testing through corresponding PV technologies.

Acknowledgments: This work was achieved at the Renewable Energy Sciences and Engineering Department of the Faculty of Postgraduate Studies for Advanced Sciences of Beni-Suef University (Egypt). The author (Karim Menoufi) would like to thank M.H. Khedr-the principal investigator of the project "Design, implementation, and performance of a 5 KW roof top grid connected PV system: As a case study (2015-2017)" and A. Ali. Farghali (Beni-Suef University, Egypt), and Hamdy F.M. Mohamed (Al Minia Univesity, Egypt) for their support to this work. The author would also like to thank Amr Farouk (Oasis Renewable Energy Company, Egypt) for supporting the PVSI concept and for his willingness to collaborate with Beni-Suef University in institutional research projects.

Conflicts of Interest: The author declares no conflict of interest.

\section{References}

1. Battisti, R.; Corrado, A. Evaluation of technical improvements of photovoltaic systems through life cycle assessment methodology. Energy 2005, 30, 952-967. [CrossRef]

2. Dale, M. A Comparative Analysis of Energy Costs of Photovoltaic, Solar Thermal, and Wind Electricity Generation Technologies. Appl. Sci. 2013, 3, 325-337. [CrossRef]

3. Crawford, R.H.; Treloar, G.J.; Fuller, R.J.; Bazilian, M. Life-cycle energy analysis of building integrated photovoltaic systems (BiPVs) with heat recovery unit. Renew. Sustain. Energy Rev. 2006, 10, 559-575. [CrossRef] 
4. Ghosh, T.; Panicker, J.S.; Nair, V.C. Self-Assembled Organic Materials for Photovoltaic Application. Polymers 2017, 9, 112. [CrossRef]

5. Myong, S.Y.; Jeon, S.W. Efficient outdoor performance of esthetic bifacial a-Si:H semi-transparent PV modules. Appl. Energy 2016, 164, 312-320. [CrossRef]

6. Chong, K.; Khlyabich, P.P.; Hong, K.; Reyes-Martinez, M.; Rand, B.P.; Loo, Y. Comprehensive method for analyzing the power conversion efficiency of organic solar cells under different spectral irradiances considering both photonic and electrical characteristics. Appl. Energy 2016, 180, 516-523. [CrossRef]

7. Bahattab, M.A.; Alhomoudi, I.A.; Alhussaini, M.I.; Mirza, M.; Hegmann, J.; Glaubitt, W.; Löbmann, P. Anti-soiling surfaces for PV applications prepared by sol-gel processing: Comparison of laboratory testing and outdoor exposure. Sol. Energy Mater. Sol. Cells 2016, 157, 422-428. [CrossRef]

8. Esposito, S.; D'Angelo, A.; Antonaia, A.; Castaldo, A.; Ferrara, M.; Addonizio, M.L.; Guglielmo, A. Optimization procedure and fabrication of highly efficient and thermally stable solar coating for receiver operating at high temperature. Sol. Energy Mater. Sol. Cells 2016, 157, 429-437. [CrossRef]

9. Kommalapati, R.; Kadiyala, A.; Shahriar, T.; Huque, Z. Review of the Life Cycle Greenhouse Gas Emissions from Different Photovoltaic and Concentrating Solar Power Electricity Generation Systems. Energies 2017, 10, 350. [CrossRef]

10. Hu, A.H.; Huang, L.H.; Lou, S.; Kuo, C.; Huang, C.; Chian, K.; Chien, H.; Hong, H. Assessment of the Carbon Footprint, Social Benefit of Carbon Reduction, and Energy Payback Time of a High-Concentration Photovoltaic System. Sustainability 2017, 9, 27. [CrossRef]

11. Yu, M.; Halog, A. Solar Photovoltaic Development in Australia-A Life Cycle Sustainability Assessment Study. Sustainability 2015, 7, 1213-1247. [CrossRef]

12. Bonamente, E.; Pelliccia, L.; Merico, M.C.; Rinaldi, S.; Petrozzi, A. The Multifunctional Environmental Energy Tower: Carbon Footprint and Land Use Analysis of an Integrated Renewable Energy Plant. Sustainability 2015, 7, 13564-13584. [CrossRef]

13. Lamnatou, C.; Chemisana, D. A critical analysis of factors affecting photovoltaic-green roof performance. Renew. Sustain. Energy Rev. 2015, 43, 264-280. [CrossRef]

14. Chemisana, D. Building Integrated Concentrating Photovoltaics: A review. Renew. Sustain. Energy Rev. 2011, 15, 603-611. [CrossRef]

15. Collados, M.V.; Chemisana, D.; Atencia, J. Holographic solar energy systems: The role of optical elements. Renew. Sustain. Energy Rev. 2016, 59, 130-140. [CrossRef]

16. Ndiaye, A.; Charki, A.; Kobi, A.; Kébé, C.M.F.; Ndiaye, P.A.; Sambou, V. Degradations of silicon photovoltaic modules: A literature review. Sol. Energy 2013, 96, 140-151. [CrossRef]

17. Ndiaye, A.; Kébé, C.M.F.; Ndiaye, P.A.; Charki, A.; Kobi, A.; Sambou, V. A Novel Method for Investigating Photovoltaic Module Degradation. Energy Procedia 2013, 36, 1222-1231. [CrossRef]

18. Wang, E.; Yang, H.E.; Yen, J.; Chi, S.; Wang, C. Failure Modes Evaluation of PV Module via Materials Degradation Approach. Energy Procedia 2013, 33, 256-264. [CrossRef]

19. Oreski, G.; Wallner, G.M. Aging mechanisms of polymeric films for PV encapsulation. Sol. Energy 2005, 79, 612-617. [CrossRef]

20. Siddiqui, R.; Kumar, R.; Jha, G.K.; Gowri, G.; Morampudi, M.; Rajput, P.; Lata, S.; Agariya, S.; Dubey, B.; Nanda, G.; et al. Comparison of different technologies for solar PV (Photovoltaic) outdoor performance using indoor accelerated aging tests for long term reliability. Energy 2016, 107, 550-561. [CrossRef]

21. Bogard, M. Empirical Methods-A Review: With an Introduction to Data Mining and Machine Learning; Economics Faculty Publications: Bowling Green, KY, USA, 2011; Available online: http:/ /digitalcommons.wku.edu/ econ_fac_pub/10 (accessed on 27 May 2017).

22. Campbell, D.; Stanley, J. Experimental and Quasi-Experimental Designs for Research; Houghton Mifflin Company: Boston, MA, USA, 1963.

23. Wieringa, R. Empirical research methods for technology validation: Scaling up to practice. J. Syst. Softw. 2014, 95, 19-31. [CrossRef]

24. Mani, M.; Pillai, R. Impact of dust on solar photovoltaic (PV) performance: Research status, challenges and recommendations. Renew. Sustain. Energy Rev. 2010, 14, 3124-3131. [CrossRef]

25. Mekhilef, S.; Saidur, R.; Kamalisarvestani, M. Effect of dust, humidity and air velocity on efficiency of photovoltaic cells. Renew. Sustain. Energy Rev. 2012, 16, 2920-2925. [CrossRef] 
26. Darwish, Z.A.; Kazem, H.A.; Sopian, K.; Alghoul, M.A.; Chaichan, M.T. Impact of Some Environmental Variables with Dust on Solar Photovoltaic (PV) Performance: Review and Research Status. Int. J. Energy Environ. 2013, 7, 152-159.

27. Sarver, T.; Al-Qaraghuli, A.; Kazmerski, L.L. A comprehensive review of the impact of dust on the use of solar energy: History, investigations, results, literature, and mitigation approaches. Renew. Sustain. Energy Rev. 2013, 22, 698-733. [CrossRef]

28. Ghazi, S.; Ip, A.S.K. Dust effect on flat surfaces-A review paper. Renew. Sustain. Energy Rev. 2014, 33, 742-751. [CrossRef]

29. Kazem, A.A.; Chaichan, M.T.; Kazem, H.A. Dust effect on photovoltaic utilization in Iraq: Review article. Renew. Sustain. Energy Rev. 2014, 37, 734-749. [CrossRef]

30. Sayyah, A.; Horenstein, M.N.; Mazumder, M.K. Energy yield loss caused by dust deposition on photovoltaic panels. Sol. Energy 2014, 107, 576-604. [CrossRef]

31. Darwish, Z.A.; Kazem, H.A.; Sopian, K.; Al-Goul, M.A.; Alawadhi, H. Effect of dust pollutant type on photovoltaic performance. Renew. Sustain. Energy Rev. 2015, 41, 735-744. [CrossRef]

32. Costa, S.C.S.; Diniz, A.S.A.C.; Kazmerski, L.L. Dust and soiling issues and impacts relating to solar energy systems: Literature review update for 2012-2015. Renew. Sustain. Energy Rev. 2016, 63, 33-61. [CrossRef]

33. Maghami, M.R.; Hizam, H.; Gomes, C.; Radzi, M.A.; Rezadad, M.I.; Hajighorbani, S. Power loss due to soiling on solar panel: A review. Renew. Sustain. Energy Rev. 2016, 59, 1307-1316. [CrossRef]

34. Zaihidee, F.M.; Mekhilef, S.; Seyedmahmoudian, M.; Horan, B. Dust as an unalterable deteriorative factor affecting PV panel's efficiency: Why and how. Renew. Sustain. Energy Rev. 2016, 65, 1267-1278. [CrossRef]

35. Said, S.A.M. Effects of dust accumulation on performances of thermal and photovoltaic flat-plate collectors. Appl. Energy 1990, 37, 73-84. [CrossRef]

36. El-Shobokshy, M.S.; Hussein, F.M. Effect of dust with different physical properties on the performance of photovoltaic cells. Sol. Energy 1993, 51, 505-511. [CrossRef]

37. El-Shobokshy, M.S.; Hussein, F.M. Degradation of photovoltaic cell performance due to dust deposition on to its surface. Renew. Energy 1993, 3, 585-590. [CrossRef]

38. Goossens, D.; Van Kerschaever, E. Aeolian dust deposition on photovoltaic solar cells: The effects of wind velocity and airborne dust concentration on cell performance. Sol. Energy 1999, 66, 277-289. [CrossRef]

39. Bouaouadja, N.; Bouzid, S.; Hamidouche, M.; Bousbaa, C.; Madjoubi, M. Effects of sandblasting on the efficiencies of solar panels. Appl. Energy 2000, 65, 99-105. [CrossRef]

40. Asl-Soleimani, E.; Farhangi, S.; Zabihi, M.S. The effect of tilt angle, air pollution on performance of photovoltaic systems in Tehran. Renew. Energy 2001, 459-468. [CrossRef]

41. Elminir, H.K.; Ghitas, A.E.; Hamid, R.H.; El-Hussainy, F.; Beheary, M.M.; Abdel-Moneim, K.M. Effect of dust on the transparent cover of solar collectors. Energy Convers. Manag. 2006, 47, 3192-3203. [CrossRef]

42. Kaldellis, J.K.; Kokala, A. Quantifying the decrease of the photovoltaic panels' energy yield due to phenomena of natural air pollution disposal. Energy 2010, 35, 4862-4869. [CrossRef]

43. Vivar, M.; Herrero, R.; Antón, I.; Martínez-Moreno, F.; Moretón, R.; Sala, G.; Blakers, A.W.; Smeltink, J. Effect of soiling in CPV systems. Sol. Energy 2010, 84, 1327-1335. [CrossRef]

44. Jiang, H.; Lu, L.; Sun, K. Experimental investigation of the impact of airborne dust deposition on the performance of solar photovoltaic (PV) modules. Atmos. Environ. 2011, 45, 4299-4304. [CrossRef]

45. Kaldellis, J.K.; Kapsali, M. Simulating the dust effect on the energy performance of photovoltaic generators based on experimental measurements. Energy 2011, 36, 5154-5161. [CrossRef]

46. García, M.; Marroyo, L.; Lorenzo, E.; Pérez, M. Soiling and other optical losses in solar-tracking PV plants in navarra. Prog. Photovolt. Res. Appl. 2011, 19, 211-217. [CrossRef]

47. Kaldellis, J.K.; Fragos, P.; Kapsali, M. Systematic experimental study of the pollution deposition impact on the energy yield of photovoltaic installations. Renew. Energy 2011, 36, 2717-2724. [CrossRef]

48. Pavan, A.M.; Mellit, A.; De Pieri, D. The effect of soiling on energy production for large-scale photovoltaic plants. Sol. Energy 2011, 85, 1128-1136. [CrossRef]

49. Ibrahim, A. Effect of Shadow and Dust on the Performance of Silicon Solar Cell. J. Basic Appl. Sci. Res. 2011, 1, 222-230.

50. Sulaiman, S.A.; Hussain, H.H.; Leh, N.S.H.N.; Razali, M.S.I. Effects of Dust on the Performance of PV Panels. Int. Sch. Sci. Res. Innov. 2011, 5, 2028-2033. 
51. Cabanillas, R.E.; Munguia, H. Dust accumulation effect on efficiency of Si photovoltaic modules. J. Renew. Sustain. Energy 2011, 3, 043114. [CrossRef]

52. Kaldellis, J.K.; Fragos, P. Ash deposition impact on the energy performance of photovoltaic generators. J. Clean. Prod. 2011, 19, 311-317. [CrossRef]

53. Beattie, N.S.; Moir, R.S.; Chacko, C.; Buffoni, G.; Roberts, S.H.; Pearsall, N.M. Understanding the effects of sand and dust accumulation on photovoltaic modules. Renew. Energy 2012, 48, 448-452. [CrossRef]

54. Mohamed, A.O.; Hasan, A. Effect of Dust Accumulation on Performance of Photovoltaic Solar Modules in Sahara Environment. J. Basic Appl. Sci. Res. 2012, 2, 11030-11036.

55. Rahman, M.M.; Islam, M.A.; Karim, A.H.M.Z.; Ronee, A.H. Effects of Natural Dust on the Performance of PV Panels in Bangladesh. Int. J. Mod. Educ. Comput. Sci. 2012, 10, 26-32. [CrossRef]

56. Benatiallah, A.; Ali, A.M.; Abidi, F.; Benatiallah, D.; Harrouz, A.; Mansouri, I. Experimental Study of Dust Effect in Mult-Crystal PV Solar Module. Int. J. Multidiscip. Sci. Eng. 2012, 3, 1-4.

57. Sanusi, Y.K. The Performance of Amorphous Silicon PV System under Harmattan dust conditions in a Tropical Area. Pac. J. Sci. Technol. 2012, 13, 168-175.

58. Kalogirou, S.A.; Agathokleous, R.; Panayiotou, G. On-site PV characterization and the effect of soiling on their performance. Energy 2013, 51, 439-446. [CrossRef]

59. Adinoyi, M.J.; Said, S.A.M. Effect of dust accumulation on the power outputs of solar photovoltaic modules. Renew. Energy 2013, 60, 633-636. [CrossRef]

60. Kazem, H.A.; Khatib, T.; Sopian, K.; Buttinger, F.; Elmenreich, W.; Albusaidi, A.S. Effect of Dust Deposition on the Performance of Multi-Crystalline Photovoltaic Modules Based on Experimental Measurements. Int. J. Renew. Energy Res. 2013, 3, 50-853.

61. Zorrilla-Casanova, J.; Piliougine, M.; Carretero, J.; Bernaola-Galván, P.; Carpena, P.; Mora-López, L.; Sidrach-de-Cardona, M. Losses produced by soiling in the incoming radiation to photovoltaic modules. Prog. Photovolt. Res. Appl. 2013, 21, 790-796. [CrossRef]

62. Kumar, E.S.; Sarkar, D.B.; Behera, D.K. Soiling and Dust Impact on the Efficiency and the Maximum Power Point in the Photovoltaic Modules. Int. J. Eng. Res. Technol. 2013, 2, 1-8.

63. Appels, R.; Lefevre, B.; Herteleer, B.; Goverde, H.; Beerten, A.; Paesen, R.; De Medts, K.; Driesen, J.; Poortmans, J. Effect of soiling on photovoltaic modules. Sol. Energy 2013, 96, 283-291. [CrossRef]

64. Mejia, F.; Kleissl, J.; Bosch, J.L. The Effect of Dust on Solar Photovoltaic Systems. Energy Procedia 2014, 49, 2370-2376. [CrossRef]

65. Sulaiman, S.A.; Singh, A.K.; Mokhtar, M.M.M.; Bou-Rabee, M.A. Influence of Dirt Accumulation on Performance of PV Panels. Energy Procedia 2014, 50, 50-56. [CrossRef]

66. Rao, A.; Pillai, R.; Mani, M. Praveen Ramamurthy, Influence of Dust Deposition on Photovoltaic Panel Performance. Energy Procedia 2014, 54, 690-700. [CrossRef]

67. Weber, B.; Quiñones, A.; Almanza, R.; Duran, M.D. Performance Reduction of PV Systems by Dust Deposition. Energy Procedia 2014, 57, 99-108. [CrossRef]

68. Ghazi, S.; Ip, K. The effect of weather conditions on the efficiency of PV panels in the southeast of UK. Renew. Energy 2014, 69, 50-59. [CrossRef]

69. Said, S.A.M.; Walwil, H.M. Fundamental studies on dust fouling effects on PV module performance. Sol. Energy 2014, 107, 328-337. [CrossRef]

70. Kumar, S.; Chaurasia, P.B.L. Experimental Study on the Effect of Dust Deposition on Solar Photovoltaic Panel in Jaipur (Rajasthan). Int. J. Sci. Res. 2014, 3, 1690-1693.

71. Qasem, H.; Betts, T.R.; Müllejans, H.; AlBusairi, H.; Gottschalg, R. Dust-induced shading on photovoltaic modules. Prog. Photovolt. Res. Appl. 2014, 22, 218-226. [CrossRef]

72. Lorenzo, E.; Moretón, R.; Luque, I. Dust effects on PV array performance: In-field observations with non-uniform patterns. Prog. Photovolt. Res. Appl. 2014, 22, 666-670. [CrossRef]

73. Jiang, Y.; Lu, L. A Study of Dust Accumulating Process on Solar Photovoltaic Modules with Different Surface Temperatures. Energy Procedia 2015, 75, 337-342. [CrossRef]

74. Semaoui, S.; Hadj Arab, A.H.; Boudjelthia, E.K.; Bacha, S.; Zeraia, H. Dust Effect on Optical Transmittance of Photovoltaic Module Glazing in a Desert Region. Energy Procedia 2015, 74, 1347-1357. [CrossRef]

75. Ali, A.H.H.; ElDin, A.M.S.; Abdel-Gaied, S.M. Effect of Dust and Ambient Temperature on PV Panels Performance in Egypt. Jourdan J. Phys. 2015, 8, 113-124. 
76. Rahman, M.M.; Hasanuzzaman, M.; Rahim, N.A. Effects of various parameters on PV-module power and efficiency. Energy Convers. Manag. 2015, 103, 348-358. [CrossRef]

77. Klugmann-Radziemska, E. Degradation of electrical performance of a crystalline photovoltaic module due to dust deposition in northern Poland. Renew. Energy 2015, 78, 418-426. [CrossRef]

78. Kazem, H.A.; Chaichan, M.T.; Saif, S.A.; Dawood, A.A.; Salim, S.A.; Rashid, A.A.; Alwaeli, A.A. Experimental Investigations of Dust Type Effect on Photovoltaic Systems in North Region, Oman. Int. J. Sci. Eng. Res. 2015, 6, 293-298.

79. Alnaser, N.W.; Dakhel, A.A.; Al Othman, M.J.; Batarseh, I.; Lee, J.K.; Najmaii, S.; Alnaser, W.E. Dust Accumulation Study on the Bapco 0.5 MWp PV Project at University of Bahrain. Int. J. Power Renew. Energy Syst. 2015, 2, 38-54.

80. Tanesab, J.; Parlevliet, D.; Whale, J.; Urmee, T.; Pryor, T. The contribution of dust to performance degradation of PV modules in a temperate climate zone. Sol. Energy 2015, 120, 147-157. [CrossRef]

81. Dastoori, K.; Al-Shabaan, G.; Kolhe, M.; Thompson, D.; Makin, B. Impact of accumulated dust particles' charge on the photovoltaic module performance. J. Electrost. 2016, 79, 20-24. [CrossRef]

82. Al-Hitmi, F.T.M.A.; Chowdhury, N.A.; Hamad, J.A.; Gonzales, A.J.R.S.P. Investigation of solar PV performance under Doha weather using a customized measurement and monitoring system. Renew. Energy 2016, 89, 564-577. [CrossRef]

83. Saidan, M.; Albaali, A.G.; Alasis, E.; Kaldellis, J.K. Experimental study on the effect of dust deposition on solar photovoltaic panels in desert environment. Renew. Energy 2016, 92, 499-505. [CrossRef]

84. Urrejola, E.; Antonanzas, J.; Ayala, P.; Salgado, M.; Ramírez-Sagner, G.; Cortés, C.; Pino, A.; Escobar, R. Effect of soiling and sunlight exposure on the performance ratio of photovoltaic technologies in Santiago, Chile. Energy Convers. Manag. 2016, 114, 338-347. [CrossRef]

85. Lopez-Garcia, J.; Pozza, A.; Sample, T. Long-term soiling of silicon PV modules in a moderate subtropical climate. Sol. Energy 2016, 130, 174-183. [CrossRef]

86. Al Shehri, A.; Parrott, B.; Carrasco, P.; Al Saiari, H.; Taie, I. Impact of dust deposition and brush-based dry cleaning on glass transmittance for PV modules applications. Sol. Energy 2016, 135, 317-324. [CrossRef]

87. Lu, H.; Lu, L.; Wang, Y. Numerical investigation of dust pollution on a solar photovoltaic (PV) system mounted on an isolated building. Appl. Energy 2016, 180, 27-36. [CrossRef]

88. Ramli, M.A.M.; Prasetyono, E.; Wicaksana, R.W.; Windarko, N.A.; Sedraoui, K.; Al-Turki, Y.A. On the investigation of photovoltaic output power reduction due to dust accumulation and weather conditions. Renew. Energy 2016, 99, 836-844. [CrossRef]

89. Paudyal, B.R.; Shakya, S.R. Dust accumulation effects on efficiency of solar PV modules for off grid purpose: A case study of Kathmandu. Sol. Energy 2016, 135, 103-110. [CrossRef]

90. Kazem, H.A.; Chaichan, M.T. Experimental analysis of the effect of dust's physical properties on photovoltaic modules in Northern Oman. Sol. Energy 2016, 139, 68-80. [CrossRef]

91. Zarei, T.; Abdolzadeh, M. Optical and thermal modeling of a tilted photovoltaic module with sand particles settled on its front surface. Energy 2016, 95, 51-66. [CrossRef]

92. Jiang, Y.; Lu, L. Experimentally Investigating the Effect of Temperature Differences in the Particle Deposition Process on Solar Photovoltaic (PV) Modules. Sustainability 2016, 8, 1091. [CrossRef]

93. Javed, W.; Wubulikasimu, Y.; Figgis, B.; Guo, B. Characterization of dust accumulated on photovoltaic panels in Doha, Qatar. Sol. Energy 2017, 142, 123-135. [CrossRef]

94. Mehmood, U.; Al-Sulaiman, F.A.; Yilbas, B.S. Characterization of dust collected from PV modules in the area of Dhahran, Kingdom of Saudi Arabia, and its impact on protective transparent covers for photovoltaic applications. Sol. Energy 2017, 141, 203-209. [CrossRef]

95. Abderrezek, M.; Fathi, M. Experimental study of the dust effect on photovoltaic panels' energy yield. Sol. Energy 2017, 142, 308-320. [CrossRef]

96. Guan, Y.; Zhang, H.; Xiao, B.; Zhou, Z.; Yan, X. In-situ investigation of the effect of dust deposition on the performance of polycrystalline silicon photovoltaic modules. Renew. Energy 2017, 101, 1273-1284. [CrossRef]

97. Jiang, Y.; Lu, L.; Lu, H. A novel model to estimate the cleaning frequency for dirty solar photovoltaic (PV) modules in desert environment. Sol. Energy 2016, 140, 236-240. [CrossRef]

98. Jamil, W.J.; Rahman, H.A.; Shaari, S.; Salam, Z. Performance degradation of photovoltaic power system: Review on mitigation methods. Renew. Sustain. Energy Rev. 2017, 67, 876-891. [CrossRef]

99. REN21. Renewables 2016 Global Status Report; REN21 Secretariat: Paris, France, 2016; ISBN: 978-3-9818107-0-7. 
100. Huang, J.; Wang, T.; Wang, W.; Li, Z.; Yan, H. Climate effects of dust aerosols over East Asian arid and semiarid regions. J. Geophys. Res. Atmos. 2014, 119. [CrossRef]

101. Alizadeh Choobari, O.; Zawar-Reza, P.; Sturman, A. The global distribution of mineral dust and its impacts on the climate system: A review. Atmos. Res. 2014, 138, 152-165. [CrossRef]

102. African-EU Renewable Energy Cooperation Programme. Available online: https://www.africa-eurenewables.org (accessed on 27 May 2017).

103. IRENA. Africa 2030: Roadmap for a Renewable Energy Future; IRENA: Abu Dhabi, UAE, 2015.

(C) 2017 by the author. Licensee MDPI, Basel, Switzerland. This article is an open access article distributed under the terms and conditions of the Creative Commons Attribution (CC BY) license (http:/ / creativecommons.org/licenses/by/4.0/). 